\title{
A Preliminary Research on Willingness to Pay Pet Lovers on Services in Animal Health Center
}

\author{
Mokhamad Syaefudin Andrianto ${ }^{1}$, Hardiana Widyastuti ${ }^{1}$, Farida Ratna Dewi ${ }^{1}$, \\ Nisa Zahra ${ }^{1}$, Nesti Handayani ${ }^{1}$ \\ syaefudin1@apps.ipb.ac.id, hardiana.widyastuti@apps.ipb.ac.id, farida@apps.ipb.ac.id, \\ nisazahra@apps.ipb.ac.id, nesti@apps.ipb.ac.id \\ ${ }^{1}$ Department of Management, Faculty of Economics and Management, IPB University, \\ Bogor, Indonesia 16680
}

\begin{abstract}
Pet lovers in big cities have been growing and tend to increase demand of services in animal health center. Currently, There are no pay services in Depok animal health center. However, due to over increase on demand and limited budget to improve services, local government encourage manager to asses potentially charge. So, This research aims as a preliminary research to assess willingness pet lovers to pay services on Depok animal health center. The primary data gathered by survey from 24 pet lovers who came to Depok animal health center between October- November 2019. Secondary data for benchmarking were obtained from the internet and brochures. The result showed for demographic respondent aspect dominated by women $(96 \%)$ as housewife $(63 \%)$, with average allocated budget for pets was $670.000 \mathrm{IDR} / \mathrm{month}$. Respondents came to Depok animal health center was on average 6 times annually with pets were dominated by cats $(96 \%)$. The average willingness to pay service was 25583 IDR/service. The charge is relative affordable based on other ones as benchmark
\end{abstract}

Keywords : Pets budget, Pets clinic, Service charge

\section{Introduction}

The number of Indonesian pet lovers has been growing along with middle class growth especially in big cities. Entrepreneurs and veterinarians collaborate to take this opportunity and set up business related to animal care such as feed shops, pet clinics and animal health centers. For veterinarians, charge service is uncomfortable topic to discuss [1]. However, cost and revenue should be calculate to run business.

Although visit to veterinarian is considered expensive, majority pet lovers want to invest in their pets' health for example to medical checkup or vaccinated [2]. There are some reasons why people love and want to invest in pets such as for hobbies, reducing loneliness on elderly people $[3,4]$ some times considered 
as family member[5] and connected with religius perspective to concern on animal welfare[6].

On other hand, Government has responsibility to improve animal welfare, to avoid disease spreading such as suplly vaccine in low cost [7]. Therefore, Indonesian local government provide animal health center with free of charge services. However, to set up friendly animal health center and to improve service need cost [8] while goverment has limited budget. As consequence, manager has been encouraged to improve services by affordable charge of services.

Research of willingness pet lovers to pay services had done by researchers such as willingness respondents to pay service of dog's nausea and vomitting [9], rabies vaccination [10-12], and bacteria prevention [13]. In addition, there is opportunity to develop services such as pet stress handling [14-16], pet telemedicine and online feed supply [17]. So the aim of this research is to analyze willingness pet lovers to pay services which currently no service charge in Depok animal health center.

\section{Methods}

Data gained from literature review, internet, benchmarking and interview by a questionnaire during October- November 2019. Benchmarking had done by interview business owner of pets care or pet clinics around Depok City and other local government health center that has been applied charge of service. Respondent of the research was 24 clients of Depok animal health center which currently free charge to get service. Charge service in this context as levy, paid only for basic treatment such as consultation, medical checkup and subsidized medicine.

WTP is a concept where consumers are willing to pay the maximum price or the price below it in buying a product or service. There are several methods that can be used, including using transaction data, survey data, Vikrey Auction and Becker-DeGroot-Marschack's BDM [18]. One of the popular data processing using survey data is the Contingent Valuation Method (CVM). Some researchers use CVM to measure WTP [19-21]. This research used direct survey with open ended questioner in an existing hypothetical market. Steps to apply in this research were setting up the hypotetical market, obtaining bids, calculating average WTP see equation 1, estimating bid curve, agregating data and evaluating the CVM exercise. 


$$
E W T P=\frac{\sum_{i=1}^{n} \quad W i}{n}
$$

$$
\begin{array}{ll}
\text { EWTP } & =\text { average prediction of Willingnes to pay } \\
W i & =\text { score WTP for individual item } \\
\mathrm{n} & =\text { number of respondents } \\
i & =\text { individual willingness to pay }(i=1,2, \ldots, \mathrm{n})
\end{array}
$$

\section{Results}

\subsection{Respondent Characteristics}

Pet lovers is dominated by women with good education (undergraduate) and majority is housewife (Table 1). The range of age respondent between 16 and 60 years old with average of age 42 years old. They spent budget for pets minimal $80.000 \mathrm{IDR} /$ mohth and maximum 3 million IDR/month with average $670.000 \mathrm{IDR} / \mathrm{month}$. Pet lovers come to animal health center average 6 times/year.

Table 1 Characteristics of Pet lovers $(n=24)$

\begin{tabular}{lll}
\hline Variables & Sub Variable & Percentage \\
\hline sex & Male & $4 \%$ \\
& Female & $96 \%$ \\
\hline Education & Elementary school & $4 \%$ \\
& Junior high school & $4 \%$ \\
& Senior high school & $42 \%$ \\
& Undergraduate & $46 \%$ \\
& Graduate & $4 \%$ \\
\hline Occupation & Housewife & $63 \%$ \\
& Entrepreneur & $13 \%$ \\
& Teacher & $4 \%$ \\
& Lab assistant & $4 \%$ \\
& student & $4 \%$ \\
& Retired & $8 \%$ \\
\hline
\end{tabular}




\subsection{Type of disease}

Kind of the pets is dominated by cat (95\%) and type of disease majority by diarrhea, virus and flu (Figure 1).

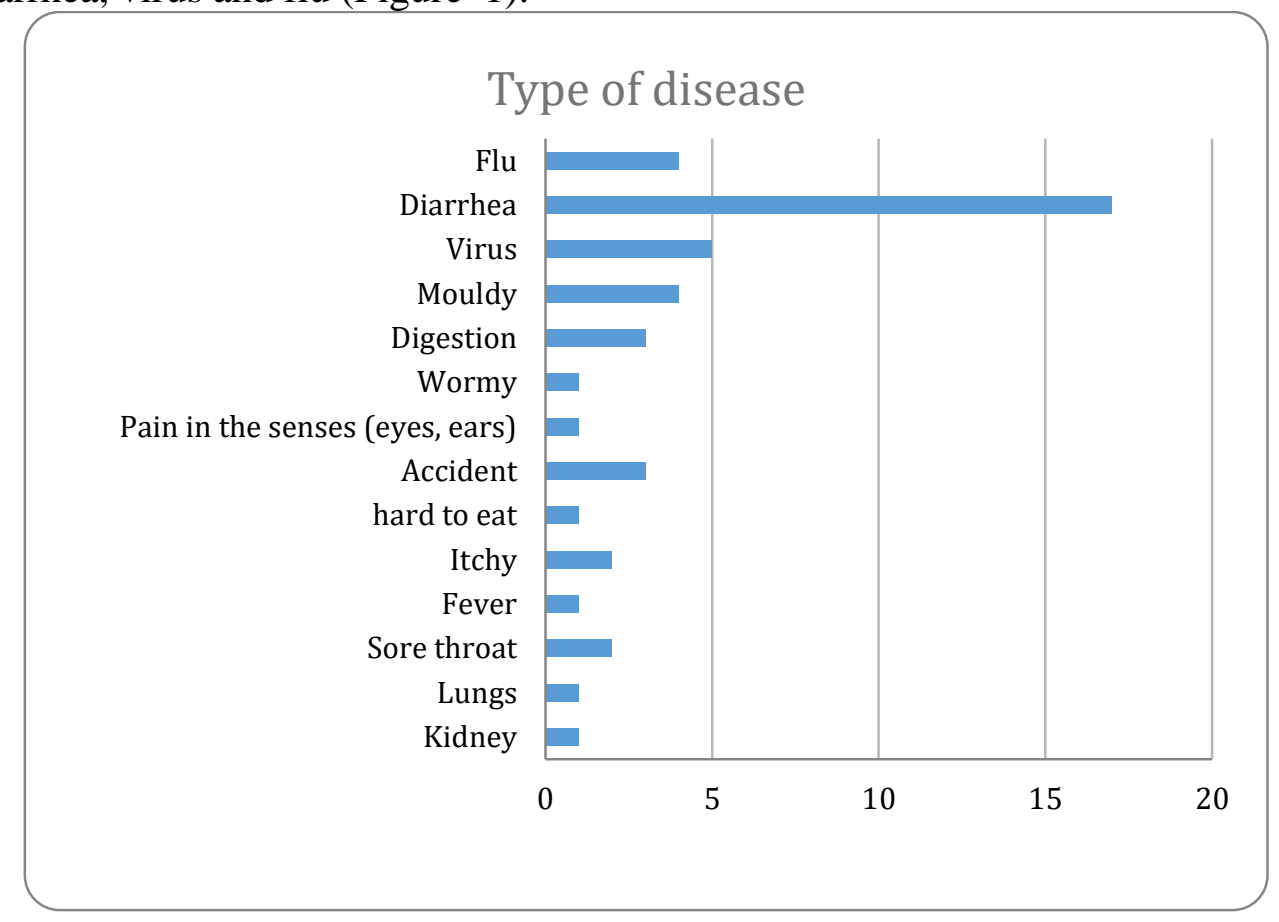

Fig.1 Type of Disease

\subsection{Willingess To Pay a service}

Direct open question to respondent had applied and majority respondent want to pay charge $(87,5 \%)$ with various number and only $13 \%$ still want free charge (Table 2). Calculation use average WTP charge (see equation 1) is 25 $583 \mathrm{IDR} /$ service. Value from the Table 2 plotted to graphic percentage of WTP and price (Figure 2). In this case, If average WTP will be applied, customer of Depok animal health center will potentially reduce into 60\% (Figure 2). 
Table 2 Willingness To Pay services in animal health center

\begin{tabular}{rrrrr}
\hline Price* & \multicolumn{4}{c}{ WTP } \\
\cline { 2 - 5 } & Number of Respondent & Percentage (\%) & Cummulative & Total * \\
\hline 50 & 8 & 33 & 33,3 & 400 \\
40 & 1 & 4 & 37,5 & 40 \\
20 & 8 & 33 & 70,8 & 160 \\
5 & 2 & 8 & 79,2 & 10 \\
2 & 2 & 8 & 87,5 & 4 \\
0 & 3 & 13 & 100,0 & - \\
\hline *price in IDR thousand & 24 & 100 & & 614 \\
\hline
\end{tabular}

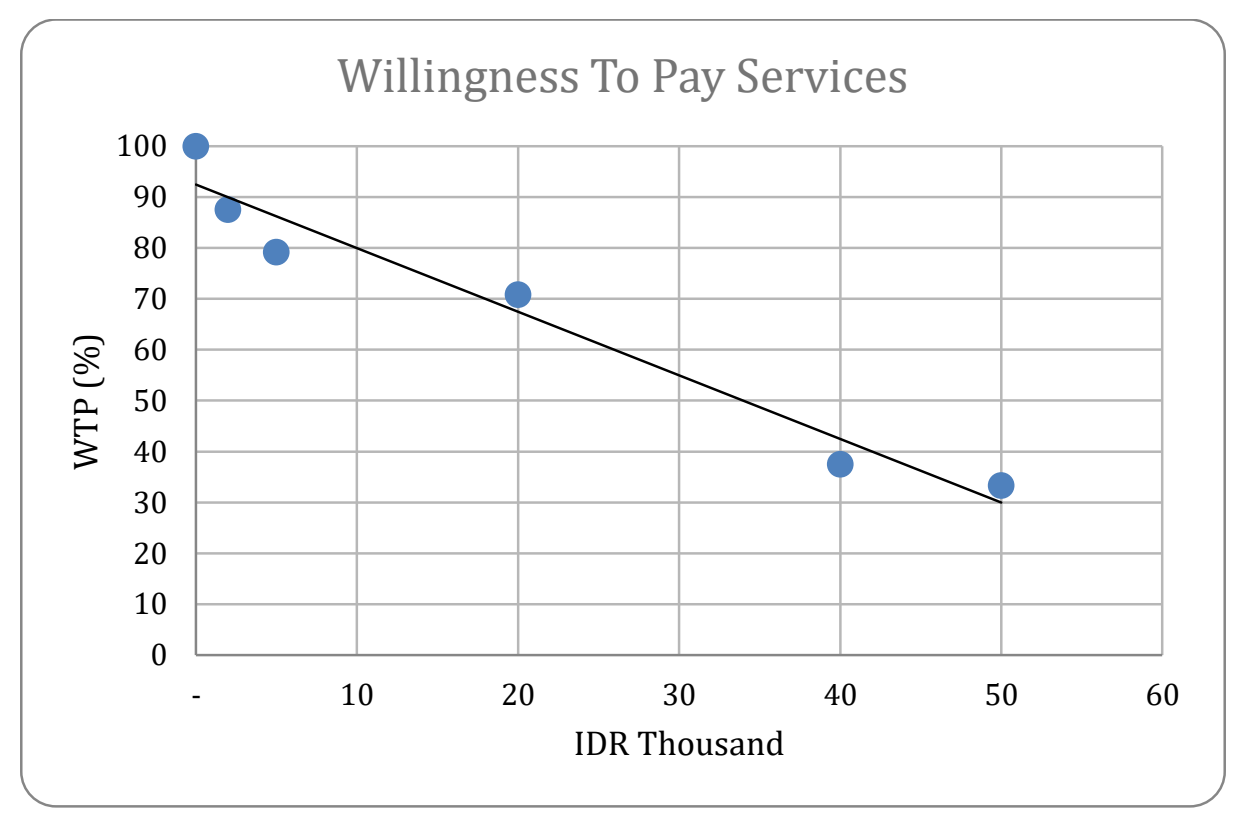

Fig.2 Charge and Willingness To Pay

Benchmarking of type of services animal clinic are various from doctor fee, vaccine, surgery until blood test and test kit. Charge of service is also various from 20 thousands IDR to over 1 million IDR. Pet lovers as customer of Depok animal health center want to simple charge in the basic services every come. 
Table 3 Type of services and animal health center charges

\begin{tabular}{|c|c|c|c|c|c|}
\hline $\begin{array}{l}\text { Type of } \\
\text { Service }\end{array}$ & $\begin{array}{r}\text { GS } \\
\text { Petclinic } \\
\end{array}$ & $\begin{array}{r}\mathrm{BG} \\
\text { Petclinic } \\
\end{array}$ & $\begin{array}{r}\text { Am } \\
\text { Petclinic } \\
\end{array}$ & $\begin{array}{r}\text { BB } \\
\text { Petshop }\end{array}$ & $\begin{array}{r}\text { Local } \\
\text { Government CM }\end{array}$ \\
\hline Doctor fee & 70 & 70 . & 50 & 50 & 20 \\
\hline Vaccine & $180-285$ & & 150 & & \\
\hline Treatment & $110-250$ & & & & 20 \\
\hline Surgery & $500-800$ & $400-1.400$ & $450-650$ & $100-800$ & $75-250$ \\
\hline Inpatient care & 60 & $150-210$ & 40 & 60 & \\
\hline Housecall & 50 & 150 & & & \\
\hline Consultation & 70 & 35 & & & \\
\hline Blood test & $150-450$ & & & & \\
\hline Test Kit & 200- 250 & $150-225$ & & & \\
\hline
\end{tabular}

* Price in IDR thousands

\section{Discussion}

Almost all pets lovers that come to Depok animal health center is house wife, average budget for pets $670.000 \mathrm{IDR} /$ month and dominated cat as pets. Even local goverment provide free service, they want to get improvement services and have willingness to pay services. However, simple charge should be applied with single price for basic services. Service price as levy recommended is 25 thousand IDR.

\section{Acknowledgments}

Thanks to government Depok City had support to gain data and grant. Thanks to Tita Ajeng had support in field survey.

\section{Reference}

[1] Donnelly AL. Talking to clients about treatment plans and fees. Proc. NORTH Am. Vet. Conf. Vol. 22, Orlando, Florida, USA, 2008, 2008, p. 216-8.

[2] Klumpers M, Endenburg N. Pets, veterinarians, and multicultural society. Tijdschr Diergeneeskd 2009; 134 .

[3] Tkatch R, Wu L, MacLeod S, Ungar R, Albright L, Russell D, et al. Reducing loneliness and improving well-being among older adults with animatronic pets. Aging Ment Heal 2020. https://doi.org/10.1080/13607863.2020.1758906.

[4] Gee NR, Mueller MK. A Systematic Review of Research on Pet Ownership and 
Animal Interactions among Older Adults. Anthrozoos 2019;32. https://doi.org/10.1080/08927936.2019.1569903.

[5] Al-Dabbagh M, Dobson S. Infectious Hazards from Pets and Domestic Animals. Adv. Exp. Med. Biol., vol. 697, 2011, p. 261-72. https://doi.org/10.1007/978-1-4419-7185$2 \_18$.

[6] Min M, Zaw CC. Animal care: an Islamic perspective with particular reference to unwanted pets- stray dogs and cats. Int J Business, Econ Law 2016;9:153-65.

[7] Thomas D, Delgado A, Louison B, Lefrancois T, Shaw J. Examining dog owners' beliefs regarding rabies vaccination during government-funded vaccine clinics in Grenada to improve vaccine coverage rates. Prev Vet Med 2013;110. https://doi.org/10.1016/j.prevetmed.2013.02.009.

[8] Endersby S. Setting up a cat friendly clinic. Vet Nurse 2018;9:284-93. https://doi.org/10.12968/vetn.2018.9.6.284.

[9] Kraus BLH, Cazlan C. Assessment of Dog Owner Concern Regarding Peri-operative Nausea and Vomiting and Willingness to Pay for Anti-emetic Treatment. Front Vet Sci 2019;6. https://doi.org/10.3389/fvets.2019.00264.

[10] Birhane MG, Miranda MEG, Dyer JL, Blanton JD, Recuenco S. Willingness to Pay for Dog Rabies Vaccine and Registration in Ilocos Norte, Philippines (2012). PLoS Negl Trop Dis 2016;10:e0004486. https://doi.org/10.1371/journal.pntd.0004486.

[11] Kadowaki H, Duc PP, Sato K, Phuong PTM, Hagiwara K, Makita K. Socio-economic factors associated with voluntary rabies control measures in Vietnam. Prev Vet Med 2018;157. https://doi.org/10.1016/j.prevetmed.2018.06.006.

[12] Barbosa Costa G, Ludder F, Monroe B, Dilius P, Crowdis K, Blanton JD, et al. Barriers to attendance of canine rabies vaccination campaigns in Haiti, 2017. Transbound Emerg Dis 2020:tbed.13622. https://doi.org/10.1111/tbed.13622.

[13] Höjgård S, Sundström K, Christensson D, Hallgren G, Hjertqvist M, Wallensten A, et al. Willingness to pay for compulsory deworming of pets entering Sweden to prevent introduction of Echinoccoccus multilocularis. Prev Vet Med 2012;106. https://doi.org/10.1016/j.prevetmed.2012.02.015.

[14] Mariti C, Bowen JE, Campa S, Grebe G, Sighieri C, Gazzano A. Guardians' Perceptions of Cats' Welfare and Behavior Regarding Visiting Veterinary Clinics. J Appl Anim Welf Sci 2016;19. https://doi.org/10.1080/10888705.2016.1173548.

[15] Hampton A, Ford A, Cox RE, Liu CC, Koh R. Effects of music on behavior and physiological stress response of domestic cats in a veterinary clinic. J Feline Med Surg 2020;22. https://doi.org/10.1177/1098612X19828131.

[16] Nibblett BM, Ketzis JK, Grigg EK. Comparison of stress exhibited by cats examined in a clinic versus a home setting. Appl Anim Behav Sci 2015;173. https://doi.org/10.1016/j.applanim.2014.10.005.

[17] Widmar NO, Bir C, Slipchenko N, Wolf C, Hansen C, Ouedraogo F. Online procurement of pet supplies and willingness to pay for veterinary telemedicine. Prev Vet Med 2020;181:105073. https://doi.org/10.1016/j.prevetmed.2020.105073.

[18] Wertenbroch K, Skiera B. Measuring Consumers' Willingness to Pay at the Point of Purchase. J Mark Res 2002;XXXIX:228-41.

[19] Priambodo LH, Najib M. Analisis Kesediaan Membayar (Willingness to Pay) Sayuran Organik dan Faktor-Faktor yang Mempengaruhinya. J Manaj Dan Organ 2016;5:1. https://doi.org/10.29244/jmo.v5i1.12125.

[20] Andrianto MS, Sukmawati Y, Syamsu K, Budijanto S, Wulandari N. Market Potential of Red Palm Oil (RPO) and Derivative Product. Int. Conf. Sustain. Bus. Compet. 
Indones. Agribus., Bogor: Bogor Agricultural University; 2012, p. 82-8.

[21] Slamet AS, Nakayasu A. Consumer Preferences for Traceable Fruit and Vegetables and Their Influencing Factor in Indonesia. Int J Sustain Futur Hum Secur 2017;5:4758. https://doi.org/10.24910/jsustain/5.1/4758. 